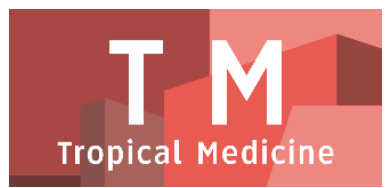

PAPER - OPEN ACCESS

\title{
Pengaruh Terapi Relaksasi Otot Progresif Terhadap Tingkat Kecemasan Pasien Kanker Payudara di RSUP Haji Adam Malik, Medan
}

\author{
Author : Rizky Rahma Nova \\ DOI $\quad: 10.32734 /$ tm.v1i1.33 \\ Paper Page : $59-66$
}

Volume 1 Issue 1 - 2018 TALENTA Conference Series: Tropical Medicine (TM)

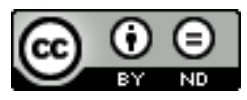

This work is licensed under a Creative Commons Attribution-NoDerivatives 4.0 International License.

Published under licence by TALENTA Publisher, Universitas Sumatera Utara
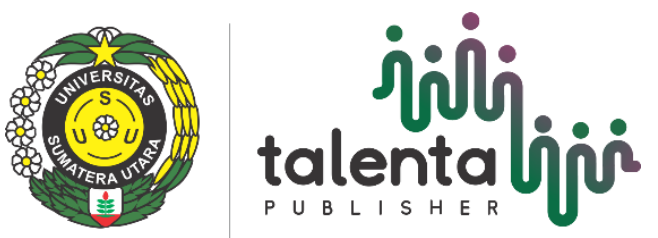


\title{
Pengaruh Terapi Relaksasi Otot Progresif Terhadap Tingkat Kecemasan Pasien Kanker Payudara di RSUP Haji Adam Malik, Medan
}

\author{
Rizky Rahma Nova ${ }^{a}$, Roxsana Devi Tumanggor ${ }^{a}$ \\ ${ }^{a}$ Departemen Keperawatan Jiwa dan Komunitas Fakultas Keperawatan, Universitas Sumatera Utara,
}

Email: rizkyrahmanovha12@gmail.com, tumanggordevi@gmail.com

\begin{abstract}
Patient with breast cancer is experienced a psychological pressure with cancer diagnosis. This condition leads to anxiety and hopeless feeling toward life. One of the therapies which found effective to minimize anxiety is progressive muscle relaxation. The objective of the reasearch was to find the influence of progressive muscle relaxation therapy as the nursing intervention in reducing the anxiety level of the patient with breast cancer. The research applied quasi experiment method with pre-test and posttest control group design. The samples involved are 26 patients with breast cancer, which consist of 13 patients with intervention and 13 patient without intervention. The research instrument used to assess the anxiety level was HRS-A (Hamilton Rating ScaleAnxiety) questionnaire. The research conducted at RSUP Haji Adam Malik Medan from May to June,2016. Progressive muscle relaxation theraphy was carried out in 3 days with the frequency of 6 times exercise. The result of the research showed that $t-$ value was -4.275 and $p$-value $=0.000$ or $p$-value $<0.05(0,000)$ which indicated that there was the influence of progressive muscle relaxation therapy on the decrease in the level of anxiety of breast cancer patients. Therefore, nurse can use progressive muscle relaxation as non-pharmacological in coping with breast cancer patients.
\end{abstract}

Keywords: Breast Cancer, Anxiety; Progressive Muscle Relaxation Therapy

\section{Pendahuluan}

Perubahan gaya hidup dan paparan lingkungan saat ini menyebabkan terjadinya pergeseran pada pola dan jenis penyakit, salah satunya adalah peningkatan insiden penyakit kanker diantara penyakit lainnya (Haryati, 2009). Kanker merupakan ancaman serius kesehatan masyarakat karena insiden dan angka kematiannya terus meningkat dari tahun ke tahun. Kanker merupakan masalah yang besar diseluruh dunia dimana 12,5\% kematian disebabkan oleh kanker (Djoerban, 2008 dalam Haryati, 2009).

Salah satu kanker yang paling sering terjadi dan menjadi penyebab kematian utama wanita adalah kanker payudara, dimana kanker ini merupakan pembunuh nomor dua dikebanyakan negara (Jong, 2005). Untuk kasus di Amerika Serikat sendiri, diperkirakan lebih dari 200.000 wanita didiagnosis dengan kanker payudara invasif (Ariestine, 2010). Sedangkan untuk kasus Indonesia, diperkirakan 18 per 100.000 penduduk wanita mengidap kanker payudara.

Kanker payudara terjadi karena terganggunya sistem pertumbuhan sel di dalam jaringan payudara, sehingga menyebabkan pertumbuhan sel menjadi tidak terkendali (REF). Beberapa faktor bisa menyebabkan kanker payudara 
seperti faktor genetik, radiasi, faktor reproduksi serta konsumsi lemak. Namun, faktor risiko ini bisa diminimalisir dengan pengobatan berdasarkan tingkat stadium kanker payudara. Pada stadium tertentu, maka tindakan operasi dengan pengangkatan payudara (Olfah, 2013). Mastektomi ini sering kali menyebabkan penderita menjadi takut dan cemas terkait penampilan dan dukungan finansial untuk perawatan selanjutnya.

Kehilangan atau kelainan pada payudara wanita menyebabkan masalah psikologis. Dampak kanker payudara dan pengobatannya terhadap aspek bio-psiko-sosio-spiritual yang telah diteliti Nurachmah (2001) pada penderita kanker payudara di dua rumah sakit besar di Jakarta menunjukkan bahwa penderita kanker payudara mengekspresikan gejala gangguan depresi dan kecemasan (Nurachmah, 1999 dalam Arika, 2008). Herawati (2005) juga mengungkapkan bahwa body image perempuan dengan kanker payudara cenderung mengalami perubahan. Jika hal ini tidak terintegrasi dengan konsep diri yang baik, maka kualitas hidup akan menurun secara drastis dan wanita yang mengalami kanker payudara akan mengalami gangguan body image.

Untuk mengatasi kecemasan sehingga bisa meningkatkan body image pasien, maka salah satu terapi yang bisa digunakan adalah terapi relaksasi. Teknik relaksasi yang sering digunakan untuk mengurangi ketegangan otot serta kecemasan adalah relaksasi otot progresif (Sheridan dan Radmacher, 1992). Latihan relaksasi progresif sebagai salah satu teknik relaksasi otot telah terbukti dalam program terapi terhadap ketegangan otot maupun mengatasi keluhan ansietas, insomnia, kelelahan, kram otot, nyeri leher dan pinggang, tekan darah tinggi, fobia ringan, dan gagap (Davis, 1995). Black dan Mantasarin (1998 dalam Damanik, 2012) juga menyatakan bahwa bahwa teknik relaksasi progresif dapat digunakan untuk mengurangi gejala gejala psikis. Relaksasi yang dihasilkan oleh metode ini dapat bermanfaat untuk menurunkan kecemasan, kontraksi otot dan memfasilitasi tidur dan meningkatkan sugesti (Herodes, 2010).

Penelitian yang dilakukan oleh Praptini, sulsitiowati dan Sunarta, (2013) mengatakan bahwa pemberian relaksasi otot progresif berpengaruh terhadap tingkat kecemasan pasien kanker payudara yang menjalani kemoterapi di Rumah Singgah Kanker Denpasar. Hasil penelitian menunjukkan bahwa pada kelompok perlakuan menunjukkan sebelum diberikan latihan relaksasi otot progresif, sebagian besar responden mengalami kecemasan berat yaitu sebanyak 6 responden (55\%), dan setelah diberikan latihan relaksasi otot progresif sebanyak 6 kali (3 hari setiap pagi dan sore) didapatkan data tidak ada responden yang mengalami kecemasan berat (0\%). Maka dari itu, penting sekali dilakukan penelitian untuk mengkaji tingkat kecemasan pasien dengan kanker payudara setela pemberian intervensi terapi relaksasi otot progresif.

\section{Tujuan Penelitian}

Tujuan penelitian adalah Mengetahui Pengaruh Terapi Relaksasi Otot Progresif Terhadap Kecemasan Pada Pasien Kanker Payudara di RSU Haji Adam Malik Medan.

\section{Metode Penelitian}

\subsection{Desain Penelitian}

Penelitian ini merupakan penelitian kuantitatif dengan metode Quasi Eksperimen. Pendekatan desain penelitian dengan pretest-posttest control group design yaitu melakukan perbandingan antara kelompok intervensi dan kelompok kontrol sebelum dan sesudah diberikan intervensi.

\subsection{Tempat dan Waktu Penelitian}

Penelitian ini merupakan penelitian kuantitatif dengan metode Quasi Eksperimen. Pendekatan desain penelitian dengan pretest-posttest control group design yaitu melakukan perbandingan antara kelompok intervensi dan kelompok kontrol sebelum dan sesudah diberikan intervensi. 


\subsection{Populasi dan Sampel}

Populasi dalam penelitian ini adalah seluruh pasien kanker payudara yg berada di RSUP Haji Adam Malik Medan. Sampel penelitian ini adalah 26 responden (13 kelompok intervensi dan 13 kelompok kontrol) yang mengalami kecemasan. Pengambilan sampel menggunakan teknik purposive sampling. Analisa uji statistik melalui 2 tahap yaitu dengan menggunakan analisa univariat dan analisa bivariat. Analisa univariat untuk mendapatkan gambaran tentang distribusi karakteristik responden. Analisa bivariat menggunakan uji Paired sampel t-test dan Independent t-test.

\section{Hasil Penelitian}

Adapun hasil yang diperoleh adalah sebagai berikut:

\subsection{Analisa Univariat}

Analisa univariat digunakan untuk mendapatkan data mengenai karakteristik responden.

Table 1. Distribusi Frekuensi dan Persentase Berdasarkan Karakteristik Responden

\begin{tabular}{lll}
\hline Karakteristik & F & $\%$ \\
\hline Usia & 7 & 27 \\
$33-43$ tahun & 11 & 42 \\
$44-54$ tahun & 8 & 31 \\
54-64 tahun & & \\
Agama & 23 & 88 \\
$\quad$ Islam & 3 & 12 \\
$\quad$ Kristen & 7 & 27 \\
Pendidikan Terakhir & 4 & 15 \\
SD & 12 & 46 \\
SMP & 3 & 12 \\
SMA & & 84 \\
Perguruan Tinggi & 22 & 8 \\
Pekerjaan & 2 & 4 \\
Ibu Rumah Tangga & 1 & 4 \\
PNS & 1 & $\%$ \\
Petani & & 85 \\
Wiraswasta & F & 8 \\
Status Pernikahan & 22 & 92 \\
\hline Karakteristik & & \\
\hline Menikah & 2 & 24 \\
Stadium & & \\
II & & \\
III & &
\end{tabular}

Berdasarkan Tabel 1 dapat dilihat bahwa sebagian bersar responden berada pada rentang usia 44-53 tahun ( $\mathrm{n}=11$; $42 \%$ ) nilai rata- rata (mean) pada usia responden adalah 48,76 dan $\mathrm{SD}=8,59$. Mayoritas responden adalah beragama Islam ( $\mathrm{n}=23 ; 88 \%)$. Berdasarkan status pernikahan, mayoritas responden berstatus menikah $(\mathrm{n}=22 ; 85 \%)$. Berdasarkan jenjang pendidikan terakhir, responden pada umumnya dengan pendidikan terakhir SMA ( $\mathrm{n}=12 ; 46 \%)$. Serta pekerjaan responden mayoritas adalah ibu rumah tangga $(\mathrm{n}=22 ; 84 \%)$. Dan mayoritas responden kanker payudara berada pada stadium III $(\mathrm{n}=24 ; 92 \%)$. 
Table 2. Deskripsi Tingkat Kecemasan Pre-Test dan Post Test pada Kelompok Intervensi

\begin{tabular}{llll}
\hline Kelompok Intervensi & Kategori Kecemasa & F & $\%$ \\
\hline Pre Test & Tidak Cemas & & \\
& Ringan & 3 & 23 \\
& Sedang & 5 & 38,5 \\
& Berat & 5 & 38,5 \\
\hline Total & & 13 & 100 \\
\hline Post Test & Tidak Cemas & 3 & 23 \\
& Ringan & 6 & 46,2 \\
& Sedang & 4 & 30,8 \\
\hline Total & Berat & - & - \\
\hline
\end{tabular}

Tabel 2 menunjukkan tingkat kecemasan pada kelompok intervensi pre dan post test. Untuk kecemasan pada kelompok intervensi pada data pre-test yang mengalami kecemasan ringan sebanyak 3 pasien (23\%), kecemasan sedang sebanyak 5 pasien $(38,5 \%)$ dan kecemasan berat sebanyak 5 pasien (38,5\%). Sedangkan pada data post-test tingkat kecemasan yang dialami adalah: yang tidak mengalami cemas sebanyak 3 pasien $(23 \%)$ kecemasan ringan sebanyak 6 pasien (46,2\%), kecemasan sedang sebanyak 4 pasien $(30,8 \%)$ dan tidak ada pasien dengan kecemasan berat $(0 \%)$.

Table 3. Deskripsi Tingkat Kecemasan Pre Test dan Post Test pada Kelompok Kelompok Kontrol

\begin{tabular}{llll}
\hline Kelompok Intervensi & Kategori Kecemasa & F & $\%$ \\
\hline Pre Test & Tidak Cemas & & \\
& Ringan & 2 & 15,3 \\
& Sedang & 5 & 38,5 \\
& Berat & 6 & 46,2 \\
\hline Total & & 13 & 100 \\
\hline Post Test & Tidak Cemas & - & - \\
& Ringan & 2 & 15,3 \\
& Sedang & 5 & 38,5 \\
& Berat & 6 & 46,2 \\
\hline Total & & 13 & 100 \\
\hline
\end{tabular}

Tabel 3 menunjukkan bahwa kecemasan pada kelompok kontrol pada data pre test dan post tes tidak mengalami perubahan yang mengalami kecemasan ringan sebanyak 2 pasien $(15,3 \%)$, kecemasan sedang 5 pasien $(38,5 \%)$ dan kecemasan berat 6 pasien $(46,2 \%)$.

\subsection{Analisa Bivariat}

Table 4. Deskripsi Tingkat Kecemasan Pre Test dan Post Test pada Kelompok Kelompok Kontrol

\begin{tabular}{cccccc}
\hline Kel.Kontrol & Mean & Mean Perbedaan & SD & t & P \\
\hline Pre Test & 26,46 & & 5,768 & $-1,425$ & 0,180 \\
& & $-0,62$ & & & \\
Post Test & 27,08 & & 6,563 & & \\
\hline
\end{tabular}

Rata-rata tingkat kecemasan pasien penderita kanker payudara pada data pre test adalah 26,46 (SD=5,768). Sedangkan pada data post test diperoleh nilai rata-rata adalah 27,08 ( $\mathrm{SD}=6,563)$. Dengan mean perbedaan adalah 0,62 . Berdasarkan uji statistik yang telah dilakukan diperoleh nilai t sebesar - 1,425 dengan nilai p 0,180 ( p >0,05) yang menunjukkan bahwa terdapat perbedaan yang tidak bermakna antara nilai rerata kecemasan pre dan post pada kelompok kontrol.

Table 5. Tingkat Kecemasan Responden Pre Test dan Post Test pada Kelompok Intervensi

\begin{tabular}{cccccc}
\hline Kel.Kontrol & Mean & Mean Perbedaan & SD & t & P \\
\hline Pre Test & 25,92 & 10,3 & 8,607 & & \\
& & 10,3 & & 8,26 & 0,00 \\
Post Test & 15,62 & & 4,942 & & \\
\hline
\end{tabular}


Setelah dilakukan uji statistik Paired Sample T Test didapat hasil penelitian bahwa pada pre test (sebelum melakukan relaksasi otot) rata-rata tingkat kecemasan pasien penderita kanker payudara adalah 25,92 (SD=8,607). Sedangkan setelah pasien melakukan terapi relaksasi otot progresif diperoleh nilai rata-rata sebesar 15,65 $(\mathrm{SD}=4,942)$ dengan nilai mean perbedaan adalah 10,3. Berdasarkan uji statistik yang telah dilakukan diperoleh nilai t sebesar 8,26. dengan nilai probabilitas $(\mathrm{p}) 0,000(\mathrm{P}<0,05)$ yang menunjukkan bahwa terdapat perbedaan yang bermakna antara nilai rerata pre dan post pada kelompok intervensi.

Table 6. Tingkat Kecemasan Responden Post Test pada Kelompok intervensi dan Kelom
\begin{tabular}{ccccc}
\hline Variabel Kecemasan & Mean & SD & t & P \\
\hline Intervensi & 15,75 & 5,136 & $-4,274$ & \\
Kontrol & 26,14 & $-7,209$ & $-4,164$ & \\
\hline
\end{tabular}

Tabel 8 menunjukkan perbedaan yang signifikan antara data post test untuk kelompok intervensi dengan kelompok kontrol. Nilai rata-rata post test untuk kelompok data kontrol adalah 26,14 (SD=7,209). Sedangkan ratarata untuk kelompok intervensi terjadi penurunan tingkat kecemasan menjadi 15,75 ( $\mathrm{SD}=5,136)$. Berdasarkan uji statistik yang telah dilakukan diperoleh nilai $t$ adalah $-4,274$, dengan nilai $\mathrm{p} 0,000(\mathrm{p}<0,05)$. Hal ini menunjukkan bahwa ada perbedaan nilai rerata kecemasan antara kelompok intervensi dengan kelompok kontrol. Maka, dapat disimpulkan bahwa ada pengaruh terapi relaksasi otot progresif terhadap penurunan tingkat kecemasan pada pasien dengan kanker payudara.

\section{Hasil Penelitian}

\subsection{Kecemasan pada Kelompok Intervensi dan Kelompok Kontrol}

Berdasarkan hasil penelitian dapat dilihat bahwa tingkat kecemasan pasien dengan kanker payudara sebelum diberikan latihan terapi relaksasi otot progresif pada kelompok intervensi adalah: sebanyak 5 pasien (38,5\%) berada pada rentang kecemasan sedang dan sebanyak 5 pasien $(38,5 \%)$ mengalami kecemasan berat. Sedangkan pada kelompok kontrol mayoritas reponden mengalami kecemasan berat sebanyak 6 pasien (46,2\%). Setelah diberikan terapi relaksasi otot progresif pada kelompok intervensi, mayoritas pasien mengalami kecemasan ringan sebanyak 6 pasien $(46,2 \%)$, dan pada kelompok kontrol (tanpa di berikan terapi relaksasi) pada data post-test mayoritas responden tetap mengalami kecemasan berat sebanyak 6 pasien (46,2\%).

Menurut penelitian Hartati (2008) di Rumah Sakit Umum Pusat Haji Adam Malik Medan bahwa dari 33 orang penderita kanker payudara sebagian besar wanita penderita kanker payudara mengalami kecemasan sedang sebesar $42,4 \%$, dan mengalami kecemasan berat sebesar 30,3\% serta kecemasan ringan sebesar 27,3\%.

\subsection{Gambaran Tingkat Kecemasan Sebelum dan Sesudah pada Kelompok Kontrol dan Intervensi.}

Berdasarkan penelitian yang dilakukan di RSUP Haji Adam Malik Medan didapakan hasil rata-rata tingkat kecemasan sebelum pemberian terapi relaksasi otot progresif yaitu 25,92 pada kelompok intervensi dan 26,46 pada kelompok kontrol. Sedangkan rata-rata tingkat kecemasan sesudah terapi relaksasi otot progresif yaitu 15,62 pada kelompok intervensi dan 27,08 pada kelompok kontrol.

Berdasarkan hasil tersebut dapat disimpulkan bahwa terjadi penurunan rata-rata tingkat kecemasan sesudah terapi relaksasi otot progresif pada kelompok intervensi, sedangkan pada kelompok kontrol terjadi peningkatan rata-rata tingkat kecemasan tanpa pemberian terapi relaksasi otot progresif. Rata-rata tingkat kecemasan pada kelompok intervensi mengalami penurunan sebanyak 10,3 poin. Sedangkan rata-rata tingkat kecemasan pada kelompok kontrol mengalami peningkatan sebanyak $-0,62$ poin.

Terjadi peningkatan pada kelompok kontrol, dikarenakan kelompok kontrol tidak diberikan intervensi terapi relaksasi otot progresif. 
Hasil penelitian ini sejalan dengan penelitian yang dilakukan oleh Maryani (2009) di RS. Dr. Hasan Sadikin Bandung yang meneliti pengaruh relaksasi otot progressif terhadap tingkat kecemasan pasien kanker payudara. Hasil penelitian menunjukkan adanya perbedaan secara bermakna sebelum dan sesudah relaksasi otot progressif pada pasien penderita kanker payudara di RS Dr. Hasan Sadikin Bandung.

Penderita kanker payudara akan mengalami tekanan psikologis paska terdiagnosis kanker. Tekanan yang sering kali muncul adalah kecemasan, insomnia, sulit berkonsentrasi, tidak nafsu makan, dan merasa putus asa yang berlebihan, hingga hilangnya semangat hidup. Kecemasan meningkat misalnya ketika sedang menunggu pengumuman hasil tes, menunggu hasil diagnosis, menunggu prosedur pemeriksaan medis, maupun ketika mengalami efek samping dari suatu penanganan medis. Kecemasan akan meningkat ketika individu membayangkan terjadinya perubahan dalam hidupnya di masa depan akibat penyakit atau akibat dari proses penanganan suatu penyakit, serta mengalami kekurangan informasi mengenai sifat suatu penyakit dan penanganannya (Lubis, 2009). Bahkan, beberapa referensi menunjukkan bahwa pasien dengan kanker payudara sering mengalami depresi paska terdiagnosis kanker oleh dokter.

\subsection{Pengaruh Terapi Relaksasi Otot Progresif terhadap Penurunan Tingkat Kecemasan}

Berdasarkan hasil penelitian yang telah dilakukan di RSUP Haji Adam Malik Medan, terapi relaksasi otot progresif yang dilakukan pada pasien sebanyak 6 kali latihan selama 3 hari yang dilakukan dua kali dalam satu hari yaitu pada siang hari dan sore hari yang setiap sesinya terdiri dari 15 menit, dilakukan uji statistik dengan menggunakan uji independent t-test di peroleh nilai $\mathrm{p}(0,000)$. Hal in berarti terdapat perbedaan yang signifikan antara mean tingkat kecemasan pada kelompok intervensi dan kelompok kontrol sehingga dapat disimpulkan bahwa terapi relaksasi otot progresif dapat menurunkan tingkat kecemasan pada pasien kanker payudara.

Berdasarkan hasil uji statistik dengan menggunakan uji t-dependen diperoleh nilai p $(0.000)<\alpha(0,05)$. Hal ini berarti ada pengaruh yang signifikan antara mean tingkat kecemasan pada kelompok intervensi dan kelompok kontrol sebelum dan sesudah latihan terapi relaksasi otot progresif sehingga dapat disimpulkan bahwa latihan terapi relaksasi otot progresif dapat menurukan tingkat kecemasan pada pasien kanker payudara. Nilai t negatif memberi makna bahwa nilai rerata kelompok intervensi lebih rendah dari nilai rerata kelompok kontrol. Hasil penelitian ini sejalan dengan penelitian yang dilakukan oleh Praptini (2015), yang menyatakan bahwa adan pengaruh relaksasi otot progressif terhadap tingkat kecemasan penderita kanker payudara di Rumah Singgah Kanker Denpasar. Penelitian tersebut menggunakan metode pengujian yang berbeda, yaitu metode Mann-Whitney U Test. Meskipun dengan lokasi dan metode pengujian yang berbeda, kedua penelitian ini menunjukkan hasil penelitian yang sama.

Hasil penelitian ini kemudian didukung oleh teori yang menyatakan bahwa terapi relaksasi otot progresif merupakan komponen dari terapi komplementer yang digunakan untuk menurunkan tingkat kecemasan dan memberikan kenyamanan (Snyder, Pestka \& Bly, 2006). Sebagai contoh, relaksasi otot sering menjadi bagian dari guided imagery. Mekanisme relaksasi otot progresif dalam menurunkan tingkat kecemasan pada seorang individu hal yang penting dikenali adalah tegangan otot ketika otot berkontraksi (tegang) maka rangsangan akan disampaikan ke otot melalui jalur saraf afferent. Tension merupakan kontraksi dari serat otot rangka yang menghasilkan sensasi tegangan. Relaksasi adalah pemanjangan dari serat serat otot tersebut yang dapat menghilangkan sensasi ketegangan setelah memahami dalam mengidentifikasi sensasi tegang, kemudian dilanjutkan dengan merasakan relaks. Ini merupakan sebuah prosedur umum untuk mengidentifikasi lokasi ketegangan, relaksasi dan merasakan perbedaan antara keadaan tegang (tension) dan relaksasi yang akan diterapkan pada semua kelompok otot utama. Dengan demikian, dalam relaksasi otot progresif diajarkan untuk mengendalikan otot-otot rangka sehingga memungkinkan setiap bagian merasakan sensasi tegang dan relaks secara sistematis (Mc Guigan dan Lehrer, 2005 dalam Damanik 2012).

Dalam hal ini, sistim saraf pusat melibatkan sistem saraf simpatis dan sistem saraf parasimpatis yang mempengaruhi beberapa organ. Walaupun demikian, terdapat perbedaan antara efek sistem saraf simpatis dan para simpatis yang berasal dari otak dan saraf tulang belakang (Andreassi, 2000 dalam Conrad dan Roth, 2006). Antara simpatik dan para simpatik bekerja saling timbal balik. Aktivasi dari sistem saraf simpatik disebut juga erotropic atau respon figh or flight, dimana organ diaktivasi untuk keadaan stress. Respon ini memerlukan energi yang cepat, sehingga hati lebih banyak melepaskan glukosa untuk menjadi bahan bakar otot sehingga metabolisme juga meningkat (Erliana, 2009). Cannon (1929) dalam Damanik (2012) mengobservasi efek dari saraf simpatis, yaitu 
meningkatkan denyut nadi, tekanan darah, hiperglikemia, dan dilatasi pupil, pernafasan meningkatkan, serta otot menjadi tegang. Hal ini sesuai dengan manifestasi yang ditimbulkan dari kecemasan pasien kanker payudara yang mencakup tanda dan gejala fisiologis, kognitif dan perilaku.

Dampak yang terjadi apabila kecemasan pada pasien kanker payudara tidak teratasi, pasien akan mengalami depresi sehingga mengganggu kualitas hidup pasien kanker payudara dan menghambat poses penyembuhan (Maryani, 2009). Maka dari itu diperlukan intervensi yang bersifat menurunkan kecemasan, dimana hal ini bisa ditemukan pada intervensi relaksasi otot progresif Davis (1995).

\section{Kesimpulan}

Kecemasan pasien kanker payudara pada kelompok intervensi sebagian besar mengalami kecemasan sedang dan berat dan pada kelompok kontrol sebagian bessar mengalami kecemasan berat. Tingkat kecemasan pasien kanker payudara pada kelompok intervensi sebelum melakukan terapi relaksasi otot progresif sebagian besar mengalami kecemasan sedang dan berat setelah melakukan terapi relaksasi otot progresif terjadi penurunan tingkat kecemasan, sebagian besar menjadi kecemasan ringan.

Tingkat kecemasan pada kelompok kontrol tanpa melakukan terpi relaksasi otot progresif sebagian besar mengalami kecemasan berat, tidak terjadi penurunan kecemasan pada kelompok kontrol. Terdapat pengaruh setelah melakukan terapi relasasi otot progresif terhadap penurunan tingkat kecemasan pada kelompok intervensi pada pasien kanker payudara di RSUP Haji Adam Malik Medan.

\section{Daftar Pustaka}

[1] Amin, M. M. (2008). Skripsi, Sindrom Depresif Pada Penderita Kanker Payudara. Medan: Departemen Psikiatri Fakultas Kedokteran Universitas Sumatera Utara

[2] Arikunto, (1998). Prosedur Penelitian dan Pendekatan Praktek. Jakarta: Rineka Cipta

[3] Atkinson, 1999. Pengantar Psikologi. Batam: Interaksara.

[4] Dalami, E., Suliswati,. Farida, P.,Rochimah., \& Banon Endang., (2009). Asuhan Keperawatan Jiwa Dengan Masalah Psikososial. Jakarta: Tim.

[5] Davis, M., Eshelman, E. R.., \& MacKay, M. (1995). Panduan relaksasi \& reduksi stres. Jakarta: EGC

[6] Damanik, D.N. (2015), Tesis, Pengaruh Progressive Muscle Relaxation terhadap Kecemasan Pasien Penyakit Ginjal Kronis yang Menjalani Hemodialisa. Medan: .Fakultas Keperawatan Universitas Sumatera Utara.

[7] Desiana, B. (2011). Skripsi, Faktor-Faktor Perilak Hopelessness pada Wanita Penderita Kanker Payudara. Semarang :Fakultas Psikologi Universitas Katolik Soegijapranata. Tidak di Publikasikan

[8] Harmono. (2010). Pengaruh relaksasi otot progresif terhadap penurunan tekanan darah pada pasien hipertensi primer di Kota Malang. Tesis. Perpustakaan FIK-UI

[9] Hawari, D. (2006). Manajemen Stress Cemas Dan Depresi, Edisi 2, Jakarta: FKUI.

[10] Hidayat, (2004). Model Konsep dan Teori Keperawatan. Jakarta: EGC

[11] Hidayat, (20013). Model Penelitian Keperawatan dan Teknik Analisis Data. Jakarta: Salemba Medika

[12] Isaacs.A. (2004). Keperawatan kesehatan jiwa dan psikiatrik edisi 3. Jakarta: EGC

[13] Kaplan, H I. \& Sadock, BJ. (1987). Ilmu kedokteran jiwa darurat. Jakarta: Widiya Medica

[14] Kaplan, H. I., Shadock, B. J., \& Grab, J. A. (2010). Buku ajar psikiatri edisi 2. Jakarta: EGC.

[15] Keliat, B.A. (2011). Manajemen Kasus Gangguan Jiwa. Jakarta: EGC

[16] Kemenkes, RI. (2013). Riset Kesehatan Dasar (Riskesdas 2013). Badan Penelitian dan Pengembangan Kesehatan, Kementrian Kesehatan RI. Diakses pada tanggal 15 Oktober 2015

[17] Kushariadi., Setyoadi. (2011). Terapi modalitas keperawatan pada klien psikogeriatrik. Jakarta. Salemba Medika.

[18] Lubis, N.L. (2009). Dukungan Sosial Pada pasien Kanker, Perlukah? Medan: USU Press

[19] Maramis W.F, 2000. Catatan Ilmu Kedokteran Jiwa. Surabaya: Airlangga University Press.

[20] Maryani . A. (2009), Skripsi, Pengaruh Progresif Muscle Relaxation Terhadap Kecemasan, Mual dan Muntah Setelah Kemoterapi pada Pasien Kanker Payudara di RS.Dr.Hasan Sadikin Bandung. Fakultas Keperawatan Univesrsitas Indonesia.

[21] Notoatmodjo, Soekidjo. (2010). Metodologi Penelitian Kesehatan. Jakarta : Rineka Cipta

[22] Nursalam, (2008). Konsep Dasar Penerapan Metodelogi Penelitian Ilmu Keperawatan. Jakarta: Salemba Medika

[23] Oetami, F., Thaha, I, L, M., \& Wahiduddin., (2014). Analisi Dampak Psikologis Pengobatan Kanker payudara Di RS Dr. Wahidin Sudiro Husodo Makassar http://repository.unhas.ac.id/bitstream/handle/123456789/10727/FRATIWI\%20OETAMI\%20 K11110330.pdf?sequence=1 dibuka tanggal 25 januari 2016.

[24] Pamungkas, Z. (2011). Deteksi Dini Kanker Payudara. Jogjakarta : Buku Biru. 
[25] Purwaningtyas, (2010). Pengaruh Terapi Relaksasi Otot Progresif Terhadap Tingkat Kecemasan pada Pasien Skizofrenia di RSJD Surakarta. Diambil tanggal 12 Oktober 2015. www.pustaka.ums.ac.id

[26] Polite \& Beck. (2010). Essential of nursing research: Methods, appraisal and utilization. $6^{\text {th }}$ Edition. Philladelphia: Lippincot Willian \& Walkins ippinacoot

[27] Polit \& Hungler (1999). Nursing research principles and methods. Philadhelpia: WB Saundrs

[28] Potter, P.A. \& Perry, A.G. (2005). Buku Ajar Fundamental Keperawatan: Konsep, Proses, dan Praktik. Edisi 4. Volume 1. Alih Bahasa: Yasmin Asih, dkk. Jakarta: EGC

[29] Praptini, K.D. (2015), Skripsi, Pengaruh Relaksasi Otot Progresif Terhadap Tingkat Kecemasan Pasien Kanker Pyudara yang Mejalani Kemoterapi di Rumah Singgah Kanker Denpasar. Fakultas Kedokteran Program Studi Ilmu Keperawatan. Universitas Udayana.

[30] Sugiyono. (2006). Metode Penelitian Administratif. Bandung : CV Alfabeta

[31] Suliswati dkk. (2005). Konsep Dasar Keperawatan Jiwa. Jakarta: EGC

[32] Stuart, Gail. W. (2006). Buku Saku Keperawatan Jiwa. Edisi ke-5. Jakarta: EGC.

[33] Snyder, M \& Lindquist, R. (2006). Complementary/alternative terapies in nursing(fifth edition). New York: Springer Publishing Company. 